\title{
A REDUÇÃO DA IDADE PENAL E A PEC 171/1993: UM DEBATE SOBRE O ESTADO DE EXCEÇÃO E AS PRISÕES DA MISÉRIA
}

\section{Thiago Fabres ${ }^{1}$}

\author{
Heleno Florindo da Silva ${ }^{2}$
}

\begin{abstract}
Resumo
A questão da redução da maioridade penal no Brasil não é debate recente - seja na academia ou na prática jurídica, seja no dia a dia dos brasileiros - pois há muito se levanta como ponto de conflito de opiniões, em diversos setores da sociedade. Portanto, a presente pesquisa buscará compreender, a partir de alguns referenciais teóricos, como Hannah Arendt, Loic Wacquant, Zygmunt Bauman, Raúl Eugênio Zaffaroni, Domenico Losurdo, Giorgio Agamben, entre outros, e sob uma perspectiva metodológica do múltiplo-dialético, como essa redução poderá ser um agente de violação aos direitos fundamentais, da condição humana da juventude brasileira, concluindo, ao final, que o recrudescimento penal, o aumento do Estado penal, na busca pela solução de problemas como a violência urbana, o sentimento de impunidade, não é o melhor caminho, pois as vítimas de Estado policialesco são, ainda mais, as classes mais pobres da sociedade, de modo que o direito penal não surge como o melhor mecanismo para a civilização do Ser.
\end{abstract}

Palavras-chave: Condição Humana; Menor Infrator; Estado de Exceção; Prisões da Miséria; PEC 171/1993.

\section{INTRODUÇÃO}

O debate acerca da redução da maioridade penal no Brasil não é recente, pois na academia, na prática jurídica ou no dia a dia dos brasileiros, já há muito se levantava como ponto sensível de debate entre os brasileiros, de modo que ainda - sobretudo hoje, com a aprovação pela Câmara dos Deputados Federais da redução da Maioridade Penal a partir da PEC 171/1993 - é uma das discussões mais polêmicas ${ }^{3}$ e controversas, haja vista o

\footnotetext{
${ }^{1}$ Doutor em Direito pela Universidade do Vale do Rio dos Sinos - UNISINOS, tendo realizado Estágio de Doutoramento pela Universidade de Coimbra (2006). Docente do Programa de Pós-Graduação Stricto Sensu em Direitos e Garantias Fundamentais da Faculdade de Direito de Vitória (FDV), nos cursos de Mestrado e Doutorado. E-mail: thiagofabres@hotmail.com.

${ }^{2}$ Doutorando em Direitos e Garantias Fundamentais pela Faculdade de Direito de Vitória (CAPES 4). Membro do Grupo de Pesquisa Estado, Democracia Constitucional e Direitos Fundamentais, do Programa de Pós-Graduação Strictu Sensu da Faculdade de Direito de Vitória. Membro Diretor da Academia Brasileira de Direitos Humanos (ABDH). Coordenador Geral do Curso de Direito da Faculdade Multivix - Cariacica/ES. Professor do Curso de Direito da Faculdade Multivix Cariacica/ES. Professor da Pós-graduação - Lato Senso - em Direito da Faculdade Multivix Cariacica/ES em parceria com o Centro de Evolução Profissional (CEP - Vitória). Professor do Centro de Evolução Profissional (CEP). Revisor da Revista do Curso de Direito da Faculdade São Geraldo (FSG). Revisor Ad Hoc da Revista da Faculdade de Direito da Universidade Federal do Goiás (UFG), da Revista Eletrônica de Direito do Centro Universitário Newton Paiva e da Revista Juris Plenum Ouro. E-mail: hfsilva16@hotmail.com

${ }^{3}$ É importante destacar que nesse debate, nos últimos anos, tomou grandes proporções sendo, contudo, que em muitos casos, tem sido guiado por interlocutores, seja da sociedade civil, política, jurídica ou, até mesmo acadêmica, desfavorecidos do necessário
} 
fato de que, além de discussões de cunho jurídico-dogmático, também traz questões de natureza social, econômica, política e cultural.

A partir de então, é possível verificar que tais discussões, em especial aquelas desta última década, têm tomado muito espaço nos meios de comunicação, seja das menores e mais singelas emissoras de rádio, até os mais amplos e difundidos meios de comunicação, tais como: jornais, revistas, as emissoras de TV, aberta ou fechada, a rede mundial de computadores através de sites e sítios virtuais de comunicação - Facebook, Twitter, Whatsapp, Messenger, e outros.

Esse fato que será discutido no presente trabalho a partir da premissa de que toda essa comunicação midiática que, em muitos casos, se dá sem qualquer tipo de amparo racional (jurídico ou não), pode desencadear a formação de uma criminologia midiática, caracterizada pela exploração do senso comum ${ }^{4}$ por meio de discursos ${ }^{5}$, sobretudo, hiperpunitivistas.

Nesta perspectiva, a importância das discussões desenvolvidas aqui está sustentada na necessidade de uma melhor compreensão dos impactos, justificativas e objetivos do discurso pró-redução da maioridade penal, contrapondo-o a uma perspectiva de diminuição - e não de alargamento - do Estado policialesco, contrária a redução da maioridade penal, ao passo que é possível, atualmente, constatarmos um preocupante crescimento de adeptos de uma pseudo vingança privada (amarrar suspeitos nus à postes como regra de combate à violência frente à impunidade de "certos elementos").

É a partir dessas necessidades que a presente pesquisa, sob um olhar metodológico múltiplo-dialético ${ }^{6}$,

conhecimento técnico exigido para tão complexa questão, que, por natureza, envolve conhecimentos que vão muito além do conhecimento do Direito, compondo assim, um cenário onde tais discussões, quase sempre, são pautadas em achismos, ou seja, um debate que não possui uma fundamentação técnica, científica, empírica, ou mesmo racional. Ressalta-se, contudo, que o conhecimento científico, produzido na acadêmica, não é - e não pode ser - visto como um vetor de afastamento daqueles "não cientistas" do debate. Todo conhecimento é válido, contudo, a racionalidade usada para o seu desenvolvimento, não pode ser pautada em um simples e limitado "eu acho isso; eu acho aquilo".

${ }^{4}$ Essa expressão aparece aqui usada como aquele conjunto de visões exaradas no contexto social, político, cultural ou econômico, que é totalmente desprovido de qualquer racionalidade, seja ela de cunho técnico, filosófico ou, atém mesmo, religioso, se assemelhando, inclusive, aos impulsos instintivos presentes na irracionalidade animal.

${ }^{5}$ Discurso esse que se vale, não raras vezes, das emoções e, principalmente, do medo do delito e da violência, do sentimento de impunidade que vem sendo disseminado à sociedade brasileira nas últimas décadas, cujo objetivo é angariar, cada vez mais, o apoio de uma população que, ao sentir-se acuada, a partir dessa construção ideológica busca a imposição de mais rigor penal como única - e última - solução para a criminalidade, em especial, a criminalidade infanto-juvenil. Sob o aspecto da ideologização de determinados símbolos, atos, palavras, tais como aqueles ínsitos à ideia lançada à sociedade brasileira acerca da necessidade do hiperpunitivismo como única saída para a redução da criminalidade, termos, que segundo Zizek, acabam se transformando em situações indiscutíveis, em ideologias. Para mais desdobramentos acerca desse ponto, ver Zizek (1996).

${ }^{6} \mathrm{O}$ paradigma múltiplo-dialético pode ser compreendido desde sua matriz grega, até a contemporaneidade, como o modelo de racionalidade capaz de possibilitar a existência de inúmeras realidades que, mesmo sendo diferentes entre si, convivem em harmonia dentro de uma mesma realidade político-social, ou seja, é o que nos possibilitará perceber a multiplicidade de existência e de modos de compreensão possíveis, bem como a compreensão de que está tudo inter-relacionado, de que tudo o que existe está ligado a ponto de ser especial para a vida em harmonia. É neste sentido que Krohling apontará para o fato de que desde sua formação mais incipiente, na Grécia antiga, a perspectiva do múltiplo dialético ser um importante marco na ascensão e promoção do debate sobre quaisquer situações, o que possibilitará, não só o surgimento, mas a necessidade de sua realização prática, do que 
que possibilita ao pesquisador extrair de sua pesquisa, diversos contornos teóricos, que se aproximam ou se distanciam, mas que podem ser vistos e utilizados como substrato para o embasamento teórico-filosófico e político-econômico, das inúmeras perspectivas acerca da possibilidade, ou não, da redução da maioridade penal no Brasil, objetivando, ao final, alcançar uma resposta satisfatória (uma síntese, ou seja, uma nova tese, que dará continuidade ao debate) ao seguinte problema:

A redução da maioridade penal, nos termos da PEC 171/1993, seja para todos os delitos ou somente para os delitos cometidos com violência, representa um recrudescimento penal do Estado brasileiro, bem como a efetivação do cárcere como instrumento de civilização do ser (adolescente e jovens menores de 18 anos em conflito com a lei), sendo, assim, capaz de violentar, os direitos fundamentais ínsitos a juventude brasileira nos termos do art. 227, da $\mathrm{CF} / 88$, sobretudo às camadas mais excluídas da sociedade política, econômica e social brasileira?

Assim, no primeiro capítulo buscaremos, a partir das discussões desenvolvidas, sobretudo, por Giorgio Agamben, traçar as linhas básicas do Estado de Exceção, visualizando a possibilidade de atrelarmos as últimas décadas da sociedade brasileira como o cenário de surgimento dessa exceção, justificativa e legitimação, de todo recrudescimento do Estado policialesco, bem como analisar o direito fundamental a proteção integral e prioritária como condição de humanidade da juventude brasileira, a partir de Hannah Arendt.

Já o segundo capítulo, dando continuidade à análise acerca dos problemas teórico-filosóficos e políticoeconômico-sociais da redução da menoridade penal, buscará, a partir da aproximação entre Domenico Losurdo e Zygmunt Bauman, analisar as influências do modelo de sociedade capitalista, fruto, sobretudo, das influências globalizantes do mercado neoliberal, provoca a existência de um sentimento de embate entre a barbárie (todos aqueles que estão fora desse contexto, em especial a juventude pobre e negra ${ }^{7}$ ) e a civilização, que desencadeará, a partir de Loic Wacquant, a busca por civilizar esses bárbaros a partir do cárcere ou, em suas palavras, através das prisões da miséria.

Por fim, é importante ressaltar que também será objeto de apreciação desta pesquisa, mesmo que perfunctoriamente, a relação existente entre o direito penal e a cultura do medo disseminada, especialmente, a partir dos índices de violência e criminalidade divulgados pelos veículos de comunicação, bem como a invenção e

\footnotetext{
hoje chamamos de diferença ou, mais recentemente, de diversidade, pois segundo ele "Os gregos já tinham saído da mitologia, pois viviam a presença de um novo marco, isto é, a realidade da pólis, que modificou profundamente a sua maneira de ser e viver. (...) a ágora (praça pública) é o principal espaço e instrumento de poder. Nesse cenário, descendências monárquicas, origens divinas da natureza e explicações mitológicas do poder não têm mais guarida. (...) tudo é debatido. As pessoas agora são iguais. Não há mais hierarquia absoluta e muito menos monarquia. (...). Esse é o marco inicial. Não há nada que não possa ser discutido. Não existem mais verdades eternas (2014, p. 23-24)". Em decorrência do espaço limitado de um artigo científico, para um aprofundamento acerca do método do Múltiplo Dialético, ver Krohling (2014, cap. 4).

${ }^{7}$ Importante trabalho acerca da questão da invisibilidade das desigualdades sociais, da subcidadania, no Brasil, sobretudo a partir da naturalização dessa desigualdade e utilização do sistema penal como instrumento de gestão desse cenário, está em Carvalho (2014, cap. 2 e 3).
} 
propagação estereótipo de inimigos $^{8}$, que acaba recaindo, sobretudo, nos jovens pobres (especialmente, negros e pardos), pertencentes às camadas mais indefesas e excluídas da sociedade brasileira.

\section{ESTADO DE EXCEÇÃO E A PROTEÇÃO INTEGRAL E PRIORITÁRIA COMO CONDIÇÃO HUMANA DA JUVENTUDE NA CF/889}

O momento em que a sociedade brasileira está situada é pautado, dentre outros aspectos, por um desdobramento complexo das relações sociais que cada dia mais necessitam do reconhecimento das inúmeras "visões e possibilidades de mundo", ou seja, do reconhecimento de que o pluralismo, além de realidade, é um direito fundamental de todos os brasileiros.

É nesse contexto de grandes mudanças que no mundo, principalmente em seu lado ocidental e nos países de modernidade tardia como o Brasil, as últimas décadas demonstraram a necessidade de transformação de paradigmas, o que, no caso pátrio, pode ser percebido com o anúncio, em 1988, dos pilares do Estado Democrático de Direito, que passa a ser o eixo condutor da constitucionalidade de todos esses países.

Portanto, fincadas as bases para se alicerçar um Estado Democrático de Direito, fruto de uma construção teórico-filosófica do século XX, cujas influências do que hoje conhecemos como "viragem linguística" da filosofia do direito marcou, sobremaneira, sua construção, é possível perceber que uma de suas características é a concepção constitucional que valoriza a pessoa humana em todos os seus aspectos.

$\mathrm{Na}$ atualidade, entretanto, essa valorização da pessoa humana, através da supremacia dos direitos humanos fundamentais, marca do citado cenário constitucional, é posta em pauta de discussão, haja vista a existência de inúmeras crises valorativo-paradigmáticas, inerentes ao modelo de produção capitalista, que desde a década passada, vem colocando tal sistema econômico, social, político e cultural, em Xeque, sobretudo pelos impactos sociais que tal situação acarreta ${ }^{10}$.

\footnotetext{
${ }^{8}$ Sobre a questão do inimigo no direito penal, ver Zaffaroni (2013, Cap. 1, p. 18 e ss.), onde o autor abordará, sobretudo, a ideia de que o inimigo não merece ser tratado como pessoa humana, ou seja, há uma coisificação, uma animalização do inimigo através do direito penal.

${ }^{9}$ Neste ponto do trabalho há uma busca pela compreensão do momento paradoxal em que estamos inseridos, bem como dos pilares que se forjaram acerca da proteção, integral e prioritária, nos termos $\mathrm{da} C \mathrm{CF} / 88$, da juventude brasileira, o que se fará a partir de uma aproximando entre Giorgio Agamben, em sua análise do estado de exceção, e Hannah Arendt, naquilo que chama de a condição humana.

${ }^{10}$ É neste contexto, que Zizek (2012, p. 13) aponta para o fato de estarmos vivendo no fim dos tempos. A partir de uma lógica construída em relação aos cinco estágios do luto - negação, raiva, barganha, depressão e aceitação - segundo ele, é possível destacarmos os cinco estágios do fim dos tempos para esse modelo de sociedade em que estamos imersos. O primeiro desses estágios é a negação, caracterizada pela a utopia liberal no momento de constitucionalização do Estado nacional, caracterizada pelo afastamento do Estado das relaçōes econômicas. É seguida da raiva, vista na realidade político-teológica que esse afastamento concretizou, haja vista as promessas liberais não terem sido cumpridas, aumentando o distanciamento entre os que não tinham acesso aos direitos básicos do Homem e aqueles que efetivamente usufruíam. $\mathrm{O}$ terceiro estágio apontado é a barganha, demonstrada através do retorno da crítica da economia política promovida pelo estado social em resposta às mazelas do liberalismo econômico. É seguido da depressão que, segundo ele, se dá em decorrência do estado social não ser capaz de reverter,
} 
Dentre tais impactos sociais, um dos mais preocupantes, é o aumento da violência, o aumento da criminalidade, o aumento da corrupção, que afeta todos os níveis, não só da sociedade civil, mas, também, da sociedade política que, nas últimas décadas, governa o país.

É neste momento de muita controvérsia, especulação e medo ${ }^{11}$, que é possível compreender o que Agamben chama de estado de exceção - uma criação da tradição democrático-revolucionária (2004, p. 16) - que vai ser tornando permanente, a ponto de se tornar um ponto de indeterminação entre o que é a democracia e o que é o autoritarismo (2004, p. 13).

Tais circunstâncias, de tempos de exceção, podem ser compreendidas melhor no contexto brasileiro, com o surgimento de reiterados casos de violência pública, que decorrem daquilo que a mídia, em geral, situa como sentimento de impunidade, um sentimento que aos poucos vai separando a sociedade a partir de uma linha imaginária, entre os cidadãos "de bem" e os "matáveis 12".

Boaventura reconhece esse problema, destacando que:

A divisão é tal que o "outro lado da linha" desaparece enquanto realidade, torna-se inexistente, e é mesmo produzido como inexistente. (...). Tudo aquilo que é produzido como inexistente é excluído de forma radical porque permanece exterior ao universo que a própria concepção aceite de inclusão considera como sendo o Outro. (...). Para além dela há apenas inexistência, invisibilidade e ausência não dialética (2007, p. 3-4).

E é a partir desse sentimento de impunidade ${ }^{13}$, portanto, que nos últimos anos a sociedade brasileira vem deflagrando verdadeira "caça" aos criminosos, que vão desde amarrá-los nus a postes, até a realização de

substancialmente, o quadro de sobreposição de um modus vivendi sobre os demais, o que pode ser visto pelo trauma social vivido após o surgimento do cogito proletário. E, por fim, a última etapa, na qual ainda estamos imersos, é a aceitação - a recuperação das causas liberais, com um novo afastamento estatal frente às relações do mercado global. É no cenário, portanto, da globalização desse neoliberalismo que nos encontramos atualmente.

${ }^{11}$ Este é o momento em que Agamben aponta para o fato de "exatamente no momento em que gostaria de dar lições de democracia a culturas e a tradiçôes diferentes, a cultura política do Ocidente não se dá conta de haver perdido por inteiro os princípios que a fundam" (2004, p. 33).

${ }^{12}$ Para uma melhor compreensão dessa expressão, ver Agamben (2002).

${ }^{13}$ Uma das causas possíveis ao aumento desse sentimento de impunidade nos últimos anos pode ser visto naquilo que Zaffaroni chama de criminologia midiática, que, ao deflagrar, incessantemente, nos vários meios de comunicação, uma minuciosa busca pela decomposição da violência, acaba gerando, além de mais violência, referido sentido na grande maioria dos populares, pois é possível perceber que o conhecimento relativo às questões criminais que a grande parte do povo brasileiro possui, decorre, dentre outros aspectos, do que os meios de comunicação lhes transmite, ou seja, quando sentam à frente de suas televisões, abrem os jornais ou revistas, acessam sites de notícias, dentre outros locais de transmissão de informação utilizados pelos veículos de comunicação, acabam construindo uma opinio, característica e peculiar, “(...) ou seja, se nutrem - ou padecem - de uma criminologia midiática" (2013, p. 194). Acerca dessa criminologia midiática, Zaffaroni (2013, p. 194) assevera, ainda, que a mesma sempre existiu, de modo que é fácil perceber na história inerente ao direito penal e seus meios de punição, bem como ao desenvolvimento da criminologia como ramo autônomo das ciências criminais, que essa espetacularização da violência nos meios de informação apelou - e ainda apela - para a criação de uma realidade sustentada "(...) em uma etiologia criminal simplista, assentada na causalidade mágica", onde a solução para as questões criminais aparece a partir de fórmulas prontas e acabadas, que não transmitem ou corroboram o necessário aprofundamento na reflexão e no debate, ou seja, se apresenta o remédio do mau, antes mesmo de se realizar o diagnóstico da patologia. Ademais, a respeito da participação da televisão como uma importante ferramenta à disposição dessa criminologia midiática, é possível perceber em Vieira que “(...) a imprensa, através do meio televisivo de comunicação constrói um modelo informativo que torna difusos os limites do real e do imaginário. Assim, as emoções criadas 
linchamentos públicos que, em muitos casos, acabam vitimando o suposto criminoso ${ }^{14}$.

Portanto, tais atrocidades que, por um lado, desumanizam o Sere, por outro, o coisificam ou animalizamno, acontecem mesmo sob os alicerces de um Estado Democrático de Direito, em que o criminoso, ou seja, o culpado, deveria ser, somente, aquele que, contra si, tem uma sentença penal condenatória, transitada em julgado, extraída de um processo penal democrático e humanizado, nos termos, por exemplo, do art. $5^{\circ}$, LIII e LVII, da $\mathrm{CF} / 88$.

Aqui Agamben nos demonstra que esse estado de exceção moderno que surge a partir desses atos de violência, cuja justificativa é a prática de uma violência anterior, “(...) é, ao contrário, uma tentativa de incluir na ordem jurídica a própria exceção, criando uma zona de indefinição em que fato e direito coincidem” (2004, p. 42).

É o que Hannah Arendt perceberá como um foco de origem de totalitarismos, pois decisões como essas demonstram que as "soluções totalitárias" ${ }^{15}$, podem muito bem sobreviver a queda de regimes totalitários, como “(...) fortes tentações que surgirão sempre que parecer impossível aliviar a miséria política, social ou econômica de um modo digno do homem" (ARENDT, 2007, p. 510).

Ainda nesse sentido, Correia aponta que o todo totalitarismo pode ser compreendido como uma forma de destruição do político, haja vista sua construção e desenvolvimento ser profundamente antipolítico, e mais:

Com efeito, enquanto a monarquia repousa sobre a honra e a república sobre a virtude, ambas respondendo à condição humana da pluralidade, a tirania se assenta sore a angústia do isolamento e do medo e o totalitarismo se apoia na experiência fundamental do desamparo. (...) no totalitarismo o terror visa a gerar indivíduos que não almejam a coisa alguma não definida na ideologia e que no seu desamparo já não participem do temor da própria aniquilação (2014, p.XV-XVI).

Contudo, os tempos de crise acabam levando a percepção de que alguns dos fundamentos desse modelo constitucional, não devem ser reconhecidos a determinadas pessoas ${ }^{16}$.

pela imagem são sentidas pelo telespectador, de forma a interagir com elas, não sendo um mero interpretador da mensagem transmitida, mas sim um integrante da mesma" (2003, p. 53).

${ }^{14}$ Neste momento em que a sociedade "se divide" à caça daqueles que, pela impunidade estatal, devem sofrer "alguma" punição social, é que Agamben destacará o fato de que "mais do que tornar o lícito o ilícito, a necessidade age aqui como justificativa para uma transgressão em um caso específico por meio de uma exceção" (2004, p. 41).

${ }^{15}$ Acerca dessas decisões totalitárias que surgem em momentos controversos e complexos como o atual, Agamben aponta que "o estado de exceção, enquanto figura da necessidade, apresenta-se, pois - ao lado da revolução e da instauração de fato de um ordenamento constitucional - como uma medida "ilegal", mas perfeitamente "jurídica e constitucional", que se concretiza na criação de novas normas" jurídicas (2004, p. 44), que podem ser vistas aqui a partir do debate atual sobre a redução da maioridade penal como fundamento de combate à impunidade, o que, mesmo violentando o sistema constitucional de proteção aos jovens, deformando a $\mathrm{CF} / 88$, pode ser visto como uma necessidade, pois, segundo Agamben, somente com os modernos é que o estado de exceção tende a ser incluído na ordem jurídica, corroborando-se a partir de uma necessidade, que se apresenta como "(...) verdadeiro "estado" da lei", haja vista essa necessidade constituir, "(...) por assim dizer, o fundamento último e a própria fonte da lei" (2004, p. 43).

${ }^{16}$ Sob esse aspecto e atrelando-o ao fato do surgimento de uma criminologia midiática no contexto atual em que sociedades como a brasileira estão inseridas, importantes são as palavras de Zaffaroni para quem "a criminologia midiática cria a realidade de um mundo de pessoas decentes, diante de uma massa de criminoso, identificada através de estereótipos, que configuram um Eles separado do resto da sociedade, por ser um conjunto de diferentes e maus. Os eles da criminologia midiática incomodam, impedem que se durma com portas e janelas abertas, perturbam as férias, ameaçam as crianças, sujam por todos os lados e, por isso, 
É nesse momento de grandes e necessárias reflexões políticas, que surge, novamente, o debate acerca da redução da maioridade penal fruto, principalmente, da Proposta de Emenda à Constituição 171, de 1993 (PEC 171/93), que atualmente tramita na Câmara dos Deputados.

Busca-se a redução da maioridade penal de 18 anos, conforme se depreende do art. 228, da CF/88, para o patamar de 16 anos. A princípio, para todo e quaisquer crimes, mas, com propostas complementares, que vão desde a redução somente para crimes violentos e/ou hediondos, à modificação do Estatuto da Criança e do Adolescente, aumentando o tempo de internação do menor infrator ${ }^{17}$, por exemplo.

A partir de então, se faz necessário, num primeiro momento, voltar os olhos à Constituição de 1988 para que seja possível compreender como se construiu, inerentemente aos jovens, todo o arcabouço normativo de sua proteção, o que, nos termos do art. 227, no referido teto constitucional, deverá se dar de forma prioritária e integral.

Antes, contudo, é importante destacar que essa proteção foi garantida aos jovens pelo esforço contínuo, não só do Estado, mas também, da sociedade e, principalmente, da família, essa que a Constituição Federal de 1988 estabeleceu como a célula mãe da sociedade ${ }^{18}$, tendo, a partir de então, proteção especial do Estado.

Isso não quer dizer que às famílias foram garantidos somente direitos, pois, como dito acima, o constituinte a incumbiu, dentre outras coisas, o dever de velar pela proteção das crianças, dos adolescentes e jovens, o que se dará, inclusive, de forma integral e prioritária.

Uma responsabilidade, um dever, que a família não carrega solitariamente, pois o divide com a Sociedade e com o Estado, conforme destaca o art. $227^{19}$, da Constituição Federal de 1988 (CF/88), que assim determina

\footnotetext{
devem ser separados da sociedade, para deixar-nos viver tranquilos, sem medos, para resolver todos nossos problemas. Para isso é necessário que a polícia nos proteja de seus assédios perversos, sem nenhum obstáculo nem limite, por que nós somos limpos, puros, imaculados" (2013, p. 197).

${ }^{17} \mathrm{~A}$ expressão "menor infrator", como significante daqueles sujeitos que, adolescentes ou jovens, com menos de 18 anos de idade, estão em conflito com a lei, é usada no presente texto a partir de uma análise crítica da mesma, por isso, aparece destacada, em todos os momentos que de seu uso, pois é sabido, e há que se ressaltar sempre tais concepções, desde o marco da transição, promovido pelo Estatuto da Criança e do Adolescente, legislação essa que buscou instaurar o paradigma da proteção integral, a partir das diretrizes constitucionais da Constituição de 1988, se buscou superar a cultura menorista, presente no antigo Código de Menores. Portanto, em decorrência dessa perspectiva histórica, usamos a expressão menor infrator, conscientes de sua impropriedade neste momento do estado da arte, pois, por tais motivos delineados acima, seu uso não é recomendável, pois nos remetem ao paradigma menorista superado pela Constituição de 1988. Ressalta-se, diante desse cenário, que o uso da expressão, criticamente, ainda é necessário na presente pesquisa, pois é a terminologia que ainda permeia todo o debate político ou apolítico, sobre o tema da redução da maioridade penal.

${ }^{18}$ É o que podemos perceber ao lermos o art. 226, da CR/88, que determina: "A família, base da sociedade, tem especial proteção do Estado".

${ }^{19} \mathrm{~A}$ partir de então, é possível destacar como a legislação especializada - Lei 8.069/90 - também assegura direitos à juventude, é o que pode ser visto, por exemplo, nos termos do art. $3^{\circ}$, da citada legislação, que determina "A criança e o adolescente gozam de todos os direitos fundamentais inerentes à pessoa humana, sem prejuízo da proteção integral de que trata esta Lei, assegurando-se-

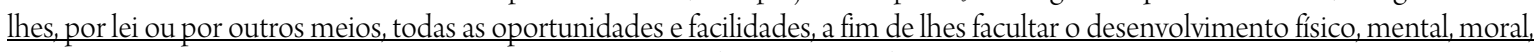
espiritual e social, em condições de liberdade e de dignidade (Grifos Nossos)".
} 
$\underline{\text { É dever da família, da sociedade e do Estado assegurar à criança, ao adolescente e ao jovem, }}$ com absoluta prioridade, o direito à vida, à saúde, à alimentação, à educação, ao lazer, à profissionalização, à cultura, à dignidade, ao respeito, à liberdade e à convivência familiar e comunitária, além de colocá-los a salvo de toda forma de negligência, discriminação, exploração, violência, crueldade e opressão (Grifos Nossos).

É a partir de então que a análise daquilo que Hannah Arendt chama de condição humana, se faz presente, haja vista a necessidade de, após identificadas as características "infantis" do Ser, a serem protegidas pelo Estado, pela Sociedade e por sua Família, buscar compreender como o aparato constitucional de 1988 criou mecanismos para a proteção desses sujeitos, o que será possível ao se analisar o princípio da proteção integral e prioritária da juventude brasileira, nos termos do art. $227, \mathrm{CF} / 88^{20}$.

É possível, portanto, visualizar a existência de um Direito Fundamental da juventude que, além de uma proteção integral e prioritária, objetiva assegurá-la um desenvolvimento físico, mental, moral e social em condições de liberdade e dignidade, o que, necessariamente, deverá passar por um meio ambiente natural equilibrado e saudável, que a afaste de toda e qualquer forma de negligência, discriminação, exploração, violência, crueldade e opressão.

Não há como não se reconhecer, neste sentido, a existência de um direito fundamental da juventude em se desenvolver de forma saudável, cabendo ao Estado, a Sociedade e, sobretudo, Família - que em regra compõem o primeiro contato social do desenvolvimento humano - garantir a concretização desse direito fundamental à proteção integral e prioritária dos jovens.

É possível compreender a partir daí que toda essa proteção se dá em decorrência da necessidade de se proteger a condição humana "juvenil" do indivíduo, ou seja, daquele sujeito que está se desenvolvendo para as relações sociais, culturais, econômicas e, sobretudo, políticas, que permearão todo o resto de sua vida.

Neste ponto, compreender as perspectivas filosóficas delineadas por Hannah Arendt em $A$ Condição Humana pode ser um importante passo na análise do problema de pesquisa lançado neste trabalho, na busca por fundamentar uma perspectiva constitucional que vê nas propostas de redução da maioridade penal não só uma inversão de todo o sistema de proteção integral e prioritária da juventude, mas, também, da própria identidade constitucional lançada pela CF/88 ao Estado Democrático brasileiro o que poderá transformá-lo e um

\section{"Frankenstein Constitucional.}

Arendt, portanto, lança em $A$ Condição Humana uma reconsideração, pois a condição humana por ela analisada, parte de seu ponto de vista acerca das mais novas experiências e de seus temores mais recentes, ou seja, o que ela propõe, portanto, “(...) é muito simples: trata-se de pensar o que estamos fazendo” (2014, p. 6).

\footnotetext{
${ }^{20}$ Conforme delimitado desde a introdução acima, o presente estudo visa abordar, de forma geral, todo o debate atual inerente à redução da maioridade penal no Brasil, ou seja, enquanto um de seus objetivos centrais a questão da redução da maioridade penal passa por uma análise do direito a proteção integral e prioritária da juventude, a partir do art. 227, da CF/88, como um instrumento lançado pela própria $\mathrm{CF} / 88$ na busca de criar mecanismos para a proteção da juventude brasileira.
} 
A análise da condição humana arendtiana, para tanto, parte de uma distinção importante para a compreensão de sua perspectiva filosófica, qual seja, a distinção entre o mundo moderno - que para Arendt, teve início com as explosões nucleares na II Guerra Mundial - e a era moderna - que em sua perspectiva compreende o espaço entre os sécs. XVII e XX -que é importante, pois é a partir daí que Arendt buscará as origens daquilo que chama de moderna alienação.

Ao partir dessa perspectiva, Arendt destacará que sua análise da condição humana se dará a partir da compreensão da era moderna de onde, cada atividade humana passou a assinalar sua localização adequada no mundo, bem como onde "os juízos históricos das comunidades políticas, mediante os quais cada uma delas determinava quais atividades da vita activa deveriam ser admitidas em público e quais deveriam ser ocultadas na privatividade" (2014, p. 96) das relações humanas.

A separação daquilo que poderia ser explicitado publicamente, daquilo que, necessariamente, deveria se resguardar no íntimo do indivíduo e no íntimo de suas relações pessoais, é uma marca da racionalidade dessa era moderna que moldou as características necessárias para a aquisição do espectro humanidade, ou seja, que lançou o que cada serdeve fazer, como deve fazer e quando fazer, a fim de ser percebido como humano.

Uma dessas condições apontadas por Arendt diz respeito ao trabalho humano, pois cada indivíduo que trabalha e consome ${ }^{21}$, será sempre um animal laborans ${ }^{22}$, que para ela “(...) é, realmente, apenas uma das espécies animais que povoam a Terra - na melhor das hipóteses, a mais desenvolvida” (2005, p. 194), e é esse animal se distinguirá dos demais pelo trabalho, pois a mundanidade dos Homens está em sua redenção pelo trabalho (2014, p. 292).

O trabalho, portanto, surge como uma condição elementar da humanidade do Homem, sendo o instrumento de sua dignidade ou, por outro lado, de sua redenção. É assim, porque através do trabalho, na era moderna, o indivíduo surge, publiciza-se, torna-se importante social, política e economicamente.

A condição humana é, portanto, uma análise do processo de inserção do homem no seu meio, bem como dos instrumentos - tais como o trabalho - que o farão desabrochar para a sociedade como um elemento

\footnotetext{
${ }^{21}$ Bem próximo dessa perspectiva arendtiana, Nietzsche aponta para uma cultura de homens mercadores, ou seja, "vemos agora surgir, de várias maneiras, a cultura de uma sociedade em que o comércio é a alma, assim como a peleja individual para os antigos gregos, e a guerra, a vitória e o direito para os romanos. O mercador sabe estimar o valor de tudo sem produzi-lo, e estimar-lhe o valor segundo a necessidade dos consumidores, não segundo suas próprias necessidades; 'quem e quantos consomem isto?' é uma grande pergunta. Esse gênero de estimativa ele emprega instintiva e incessantemente para tudo, também para as realizações da arte e da ciência, dos pensadores, doutores, artistas, estadistas, de povos e partidos, de épocas inteiras: em relação a tudo o que é produzido ele pergunta pela oferta e a demanda, a fim de estabelecer para si o valor de uma coisa. Isto alçado em caráter de toda uma cultura, pensado com o máximo de amplidão e sutileza, e impondo-se a toda vontade e capacidade: é disso que vocês, homens do próximo século $[\mathrm{XX}]$, estarão orgulhosos: se os profetas da classe mercadora tiverem razão em colocá-lo na sua posse! Mas eu tenho pouca fé em tais profetas" (2004, p. 127-128).

${ }^{22}$ Acerca dessa perspectiva Correia destacará que "a obra ou fabricação é a atividade que responde à condição humana da mundanidade, à dimensão da existência humana demandante de um mundo artificial de coisas duráveis, cuja permanência instaura, em contraposição ao tempo cíclico da vida biológica, uma temporalidade linear na qual se podem reconhecer vidas individuais, e
} 
importante, não só para sua formação, mas para a sua continuidade.

Neste sentido, o trabalho e outros aspectos inerentes à condição humana, embasarão um "segundo nascimento" ao Ser, através do qual o Homem se inserirá, com palavras e atos, na sociabilidade que o governará, bem como, que confirmará a existência física original desse Homem, desde seu nascimento biológico - o "primeiro nascimento".

As relações humanas em sociedade vão, portanto, caracterizar a existência do Homem através de elementos que são essenciais para sua existência, tais como: a política, a liberdade, os direitos e deveres fundamentais, e outros, que conformarão o que Arendt chama de condição humana.

A identidade constitucional ${ }^{23}$, os elementos que marcarão os principais contornos da Constituição de um país, a partir de então, será construída - como o foi em 1988 -através de um processo histórico, político, econômico e cultural, ou seja, é um processo em que a comunidade política - a sociedade - escolhe algumas características para conformar um modelo constitucional viável a seu desenvolvimento.

A esfera social pode ser vista, neste ponto, como o cenário em que interesses privados assumirão importância pública, ou seja, um local híbrido em que é possível perceber as várias nuances que conformam a identidade constitucional, como construção dessas relações sociais, fruto de interesses não só privados, como, também, de interesses públicos.

A CF/88, neste sentido, corrobora uma perspectiva híbrida acerca da proteção da juventude brasileira, ou seja, determina que a proteção integral e prioritária desse elemento juvenil do sujeito constitucional, é responsabilidade de todos, abrangendo, não só o público - Estado e sociedade - como, também, o privado - a família.

Assim, a menoridade penal ou a inimputabilidade dos adolescentes e jovens menores de 18 anos destacada no texto constitucional de 1988 não deve ser vista como algo banal, como algo que não tem importância para a caracterização da identidade constitucional do Estado brasileiro, pois é marca da condição humana adendtiana na (re)construção do sujeito, do indivíduo.

A "juventude" - crianças, adolescentes e jovens - protegida pela CF/88, portanto, corrobora o caráter revolucionário que marca a identidade constitucional do constituinte de 1988, pois percebeu-se, nessa grande parcela social, a necessidade de lhes garantir instrumentos capazes de protege-los de todo e qualquer tipo de negligência, violência ou qualquer outra forma de abandono.

Exigir, neste sentido, que a proteção dessa juventude, um dos pilares da $\mathrm{CF} / 88$, passe por uma "revisão para baixo", sem antes lhe proporcionar, igualitariamente, os mecanismos de proteção integral e prioritária, é que para uma maior discussão sobre a formação da identidade constitucional ver Rosenfel (2003) e (2004). 
modificar, prejudicialmente, a identidade dessa juventude construída em 1988, ou seja, é violentar as condições de humanidade necessárias para o desenvolvimento humano perfeito do $\operatorname{ser}^{24}$.

Arendt irá destacar, acerca da condição humana do ser, sua necessidade de ser visto, da esfera pública do social, como cidadão, ou seja, a cidadania é, também, um elemento de caracterização dessa condição humana, o que fará com a análise da igualdade, percebida a partir da relação entre pobres e ricos ${ }^{25}$, de modo que

Desse modo, se falamos de igualdade, a questão é sempre a seguinte: quanto temos de transformar as vidas privadas dos pobres? Em outras palavras, quanto dinheiro temos de dar a eles para torna-los aptos a desfrutar da felicidade pública? Educação é muito bom, mas o que importa mesmo é dinheiro. Somente quanto puderem desfrutar do público é que estarão dispostos e aptos a fazer sacrifícios pelo bem público. Requerer sacrifícios de indivíduos que ainda não são cidadãos é exigir deles um idealismo que eles não têm e nem podem ter em vista da urgência do processo vital. Antes de exigirmos idealismo dos pobres, devemos antes torna-los cidadãos: e isto implica transformar as circunstâncias de suas vidas privadas de modo que se tornem aptos a desfrutar do público (1977, p. 106-107).

Essa relação pode ser transfigurada para a questão problema deste trabalho, pois enquanto condição de humanidade, a cidadania dos jovens, garantida em 1988 através de instrumentos de proteção integral e prioritária dessa juventude, ainda padece de ser concretizado como algo comum a todos os jovens brasileiros, que ainda se encontram, em grandes proporções, longe de todos os meios de se alcançar essa cidadania, tais como, a educação, a segurança ${ }^{26}$, a moradia, o acesso ao trabalho digno, entre outros elementos.

\footnotetext{
${ }^{24}$ Agamben irá nos mostrar sob esse aspecto de busca pela "punição" daqueles que representam o mal em nossa sociedade, corrobora o momento em que o estado de exceção atingiu seu máximo, principalmente em realidades periféricas como a brasileira, pois, segundo ele, "o estado de exceção, hoje, atingiu exatamente seu máximo desdobramento planetário. $\mathrm{O}$ aspecto normativo do direito pode ser, assim, impunimente eliminado e contestado por uma violência governamental que, ao ignorar no âmbito externo o direito internacional e produzir no âmbito interno um estado de exceção permanente, pretende, no entanto, ainda aplicar o direito" (2004, p. 131).

${ }^{25}$ Outro elemento dessa relação trabalhado por Arendt em A Condição Humana, diz respeito ao fato de que o consumismo, na era moderna, ser o elemento essencial de caracterização da condição humana dos seres, ou seja, "(...) a capacidade humana de vida no mundo implica sempre uma capacidade de transcender e alienar-se dos processos de vida" (2014, p. 148), sendo que um dos exemplos dessa ameaça moderna, segundo Arendt está no fato de hoje todos os objetos de uso passam a ser vistos como se fossem bens de consumo, haja vista o fato de termos “(...) de consumir, devorar, por assim dizer, nossas casas, nossa mobília, nossos carros, como se estes fossem as 'coisas boas' da natureza que se deterioram inaproveitadas se não fossem arrastadas rapidamente para o ciclo interminável do metabolismo do homem com a natureza. É como se houvéssemos rompido à força as fronteiras distintivas que protegiam o mundo, o artifício humano, da natureza, tanto o processo biológico que prossegue dentro dele, quanto os processos naturais cíclicos que o rodeiam, entregando-thes e thes abandonando a sempre ameaçada estabilidade de um mundo humano (2014, p. 155)". A partir de então, Arendt aponta para o "(...) fato de que esses apetites se tornam mais sofisticados, de modo que o consumo já não se restringe às necessidades da vida, mas, ao contrário, concentra-se principalmente nas superficialidades da vida, não altera o caráter dessa sociedade, mas comporta o grave perigo de que afinal nenhum objeto do mundo esteja a salvo do consumo e da aniquilação por meio do consumo" (2014, p. 165), de modo que "(...) quanto mais fácil se tornar a vida em uma sociedade de consumidores ou de trabalhadores, mais dificil será preservar a consciência das exigências da necessidade que a compele, mesmo quando a dor e o esforço, as manifestações externas da necessidade, são quase imperceptíveis. O perigo é que tal sociedade deslumbrada pela abundância de sua crescente fertilidade e presa ao suave funcionamento de um processo interminável, já não seria capaz de reconhecer a sua própria futilidade" (2014, p. 167).

${ }^{26}$ Segundo um levantamento do Observatório de Favelas, em parceria com o Fundo das Naçōes Unidas para a Infância (Unicef), o Laboratório de Análise da Violência da Universidade do Estado do Rio de Janeiro (LAV-Uerj) e o governo federal, mais de 42 mil adolescentes poderão ser vítimas de homicídio nos municípios brasileiros com mais de 100 mil habitantes, entre 2013 e 2019. E mais, dados divulgados pelo Programa de Cidadania dos Adolescentes do Unicef mostram que, em 2011, adolescentes foram responsáveis por aproximadamente 1,8 mil homicídios no Brasil, número que corresponde a 8,4\% do total de homicídios no país.
} 
Nesse cenário de incertezas e de sentimento de insegurança, conforme visto acima, a mídia possui um papel importantíssimo, na disseminação de mais incertezas ou inseguranças, ou na busca da criação de uma perspectiva que dê a esse terreno fértil, os contornos da complexidade a ele inerentes, a fim de que o debate se dê de forma ampla, aberta, mas sem cair em falácias e argumentações sem fundamentação legal, constitucional ou, minimamente, empíricas, que acabarão violando os direitos humanos da juventude brasileira que, muito antes da garantia do cárcere, deveria ter garantidos todas as formas e instrumentos (direitos) básicos de cidadania.

Portanto, antes de se lançar discussões acerca da redução da maioridade penal, abrindo espaço para a punição penal a cada dia mais cedo, é necessário, como se pretendeu aqui, exercer uma reflexão sobre os elementos que marcam a identidade constitucional construída em 1988 e o fato dessas alterações, possivelmente, lhes serem prejudiciais.

Um discurso populista punitivo, sem o mínimo de amparo legal, constitucional ou científico, construirá no seio social, como uma verdadeira obsessão, o desejo pelo controle e pela vigilância total dos indivíduos, o que contribuirá, ainda mais, para a segregação dos grupos de risco (aqueles vulneráveis à violência, seja a praticando ou a recebendo, em seu dia-a-dia), perfazendo, assim, enquanto urgências do Estado, a fortificação e a exclusão desses marginais (WERMUTH, 2011, p. 31).

Por fim, se tais propostas impedirão que essa gigantesca parcela da sociedade brasileira se afaste, mais e mais, da concretização do conjunto de atributos (direitos e deveres) que conformarão sua cidadania, inerente a condição humana do Homem, antes de se discutir tais propostas, não estaria no momento de analisarmos se a identidade “juvenil", protegida pela CF/88 e do Estatuto da Criança e do Adolescente, foi - ou o é - respeitada nas últimas décadas, seja pela família, pela sociedade e, sobretudo, pelo Estado, nos termos do art. 227, da CF/88.

\section{A JUVENTUDE BRASILEIRA: DA BARBÁRIE A CIVILIZAÇÃO PELAS PRISÕES DA MISÉRIA}

Conforme debatido acima, as propostas de redução da maioridade penal no caso brasileiro, merecem um olhar mais acurado da situação, bem como um debate mais aprofundado sobre o tema, de modo que neste ponto, buscaremos corroborar a ideia, já lançada acima, de que essa redução fará mais mal do que bem aos brasileiros, principalmente, à sua juventude, seja para excluí-la dos benefícios inerentes ao modelo de sociedade de

Sendo que, de outro lado, no mesmo ano, 4,3 mil menores nessa faixa etária foram assassinadas. Frente ao número de adolescentes e jovens em conflito com a lei, segundo dados da Secretaria de Direitos Humanos da Presidência da República (SDH/PR) de 2012, a Idade média dos adolescentes em conflito com a lei é de 16,7 anos, sendo que $86 \%$ não concluíram o ensino básico, $43 \%$ foram criados apenas pela mãe e $17 \%$ pelos avós, $14 \%$ desses jovens têm filhos, $75 \%$ fazem uso de drogas ilícitas, $28 \%$ declararam ter sofrido agressão de funcionários e 10\% disseram apanhar da PM dentro das unidades de internação, sendo que 19\% revelaram outros castigos físicos. Todos esses dados estão disponíveis em: <http://revistaforum.com.br/digital/especial/ adolescentesencarcerados-prisao-nao-resolve-o-problema/>. 
consumo $^{27}$ predominante à sociedade mercadorizada ${ }^{28}$ atual, seja para vitimá-la a partir de sua mercadorização ${ }^{29}$.

Para tanto, buscaremos traçar, a partir de alguns referenciais teóricos, tais como: Bauman, Losurdo, Wacquant, Foucault e outros, por um lado, como o processo de não concretização dos direitos inerentes à formação digna da juventude, em contextos periféricos como o brasileiro, contribui para o reforço de condutas neoliberais de aprisionamento da miséria (neste caso, da juventude miserável brasileira).

E por outro, o fato dessas condutas terem a capacidade de vitimar grande parcela dessa juventude, dando-lhe as opções da fábrica (do trabalho informal, muitas vezes em condições de indignidade) ou do cárcere ${ }^{30}$, muito antes de lhes proteger, integral e prioritariamente, de qualquer forma de ação ou omissão que violem seus direitos fundamentais básicos.

O medo, a insegurança, o sentimento de impunidade, conforme debatido acima, portanto, poderá provocar, nesse momento de profunda crise de identidade do povo brasileiro, fruto de uma dicotomização da sociedade entre uma classe branca, burguesa, que não suporta mais financiar os benefícios assistenciais e o modelo de governo de coalização, propício, como se vê todos os dias, através dos mais importantes meios de comunicação, à corrupção, e aqueles, estigmadamente, subalternizados, que acabam percebendo nesses benefícios assistenciais do Estado, a única forma de ingresso ao "mundo do consumo", de reconhecimento através do maior acesso ao ensino superior e técnico ou, de no mínimo, ter acesso à alimentação digna para saciar a fome do dia, ou a um teto, para se proteger das intempéries do tempo.

É nesse contexto que Foucault analisará o fato do medo, desde as mais antigas civilizações, ter sido

\footnotetext{
${ }^{27}$ Sob esse aspecto Galeano destaca que "Onde se recebe a Renda per Capita? Tem muito morto de fome querendo saber. Em nossas terras, os numerinhos têm melhor sorte do que as pessoas. Quantos vão bem quando a economia vai bem? Quantos se desenvolvem com o desenvolvimento?" (2005, p. 79). E ainda, ironicamente, destaca "o que são pessoas de carne e osso? Para os mais notórios economistas, números. Para os mais poderosos banqueiros, devedores. Para os mais eficientes tecnocratas, incômodos. E para os mais exitosos políticos, votos" (2006, p. 97).

${ }^{28}$ A expressão "mecadorizada" é lançada aqui, por entendermos que o movimento do mercado global, capitalista e vindo do alto, do necessário e desejoso consumo, conforme se percebe na realidade atual, sobretudo de cunho neoliberal, acabou transformando a sociedade em um grande mercado, onde os seres humanos buscam sua sobrevivência através de um processo de competição extremo, que, mais do que nunca, transforma todos, de certo modo, em mercadorias atraentes e desejáveis (BAUMAN, 2008, p. 13), usáveis, descartáveis e, somente em alguns casos onde essa mercadoria tem muita sorte, reutilizáveis em um novo processo de consumo e descarte. Neste sentido, Bauman aponta para o fato de que se desenvolveu entre o Estado e o Mercado, atualmente, um processo de simbiose, ou seja “(...) o Estado e o Mercado, podem lutar entre si ocasionalmente, mas a relação normal e comum entre eles, num sistema capitalista, tem sido de simbiose. (...). A cooperação ente Estado e mercado no capitalismo é a regra; o conflito entre eles, quando acontece, é a exceção. Em geral, as políticas do Estado capitalista, "ditatorial" ou "democrático", são construídas e conduzidas a partir do interesse, e não contra o interesse, dos mercados; seu feito principal (e intencional, embora não abertamente declarado) é avalizar/permitir/garantir a segurança e a longevidade do domínio do mercado” (2010, p. 30-31).

${ }^{29}$ Ainda segundo Bauman, atualmente na vida para o consumo, que a sociedade contemporânea nos proporcionou, "seja lá qual for o nicho em que possam ser encaixados pelos construtores de tabelas estatísticas, todos habitam o mesmo espaço social conhecido como mercado. (...) todas as (...) pessoas, aparentemente tão distintas, são aliciadas, estimuladas ou forçadas a promover uma mercadoria atraente e desejável. (...) o teste em que precisam passar para obter os prêmios sociais que ambicionam exige que remodelem a si mesmos como mercadorias, ou seja, como produtos que são capazes de obter atenção e atrair demanda e fregueses (2008, p. 13)".

${ }^{30}$ Sobre a relação entre o cárcere e a fábrica, ver Melossi e Pavarini (2010).
} 
utilizado pelas mais arcaicas, antigas, medievais ou modernas formas de governo como um importante instrumento (fundamental em muitos casos) de controle e disciplina dos "corpos dóceis" (2013, p. 131).

Na seara penal, o medo servia aos governantes de outrora ${ }^{31} \mathrm{e}$, atualmente ao Estado, com a finalidade de convencimento àqueles que porventura querem se arriscar no mundo do crime, para que, antes de avançarem, possam antever as consequências do delito praticado, como uma verdadeira expiação daquilo que poderá lhe recair duramente.

E mais, não só para os pretensos criminosos, o medo também cumpre esse papel frente à toda coletividade, no sentido de lhes demonstrar (no presente), através do exemplo da punição dos desviantes das normas penais, o que acontecerá (no futuro) com aqueles que ousaram (no passado) transgredir a lei, alterando a ordem vigente ${ }^{32}$.

Em tempos de modernidade líquida, na acepção de Bauman, portanto, é possível identificar a utilização do medo como um fundamento de justificação para as maiores, e as mais severas, medidas punitivas e relegitimação da pena e do sistema penal.

Uma sociedade que mais e mais se mostra impulsionada pela ideologia do tudo, ao mesmo tempo e agora, ou seja, o imediatismo inerente ao sistema mundo do consumo do capital do mercado globalizado, a busca pelas respostas aos problemas que atravancam esse modelo, tais como: a criminalidade juvenil, a sua "pretensa impunidade", as taxas de violência decorrentes de práticas tomadas por adolescentes e jovens, por mais complexas que sejam, acabam seguindo a mesma dinâmica do imediatismo.

É nesse sentido, Bauman registrará que:

Os perigos que mais tememos são os imediatos: compreensivelmente, também desejamos que os remédios o sejam - 'doses rápidas', oferecendo alívio imediato, como analgésicos prontos para o consumo. Embora as raízes do perigo possam ser dispersas e confusas, queremos que nossas defesas sejam simples e prontas a serem empregadas aqui e agora. Ficamos indignados diante qualquer solução que não consiga prometer efeitos rápidos,

\footnotetext{
${ }^{31}$ Sob esse aspecto, importantes são as palavras de Foucault no sentido de que na idade média, por exemplo, o medo era usado como um dos principais objetivos que marcavam - a insanidade - o ritual dos suplícios, que exibidos em praça pública, serviam para exemplificar e reafirmar a todos, o poder e a autoridade do soberano governante no momento de aplicar as punições aos seus súditos, pois "A cerimônia do suplício coloca em plena luz a relação de força que dá poder à lei" (2013, p. 30), de modo que foi através dos suplícios, que as autoridades procuravam “(...) dar o exemplo não só suscitando a consciência de que a menor infração corria sério risco de punição; mas provocando um efeito de terror pelo espetáculo do poder tripudiando sobre o culpado" (FOUCAULT, 2013, p. 56).

${ }^{32}$ Nesse contexto é importante destacar que não só a expiação das punições, mas também, a expiação da violência, cada dia mais atroz, estampada nos meios de comunicação em massa, como verdadeiros caminhos para a concretização do direito fundamental ao acesso a "melhor" informação, acabará transformando o Homem, ou seja, o "(...) homo sapiens está se degradando em um homo videns, como efeito de uma cultura de puras imagens (...)" (ZAFFARONI, 2013, p. 196). Ainda sobre a importância dos meios de comunicação frente a assunção de um sentimento de medo e impunidade, Zaffaroni aponta para o fato dessa verdadeira criminologia midiática apresentar um discurso que percebe a punição ou a violência, como as únicas formas de se alcançar uma solução para tais conflitos. De modo que não houve, não há e nunca haverá espaço para a reparação, o tratamento, a conciliação, pois só existe salvação para o sentimento de impunidade, através de um modelo punitivo-violento eficaz, cujo alcance acarretará a limpeza da sociedade de todos aqueles indivíduos tidos como maus elementos (2013, p. 204).
} 
fáceis de atingir, exigindo em vez disso um tempo longo, talvez indefinidamente longo, para mostrar resultados (2008, p. 149).

Além da exploração do medo como elemento justificador do endurecimento do direito penal, outro importante mecanismo que surge, atrelado ao modelo político-econômico neoliberal, é a transformação, como visto acima, do Homem em mercadoria de consumo, transformando o trabalho humano, uma das condições de sua humanidade, conforme destacado por Arendt (2014), em mais uma peça da composição do sistema mundo do mercado do capital globalizado.

As pessoas que não conseguem integrar o centro de consumo e que, por via de consequência, não fazem parte dessa estética do capital, cada vez mais inerente as relações humanas, devem ser detidas, excluídas, sejam elas adultos formados (no caso brasileiro, ainda aqueles com 18 anos completos), ou não (menores de 18 anos), a fim de salvaguardar todo esse complexo de formação e dominação inerente ao modelo de sociedade construído, sobretudo, com os movimentos neoliberais desde o fim da década de $1970^{33}$.

É, portanto, nesse contexto de necessária exclusão dos indivíduos que não se adequam as regras do jogo, que surgirá um fenômeno social interessantíssimo, que Wacquant irá chamar de As Prisóes da Miséria (2001) 34.

Ainda acerca dessa temática, é interessante a premissa levantada pelo mesmo Wacquant, para quem:

Não foi tanto a criminalidade que mudou no momento atual, mas sim o olhar que a sociedade dirige para certas perturbações da via pública, isto é, em última instância, para as populações despossuídas e desonradas (pelo seu estatuto ou por sua origem) que são os seus supostos executores, para o local que elas ocupam na Cidade e para os usos aos quais essas populações podem ser submetidas nos campos político e jornalístico (2007, p. 29).

Esse Estado de emergência, que faz a gestão do medo na sociedade atual, que surge no contexto norteamericano a partir da década de 1960, e na Europa no final do século passado, conforme acentua Wacquant "não corresponde a nenhuma ruptura na evolução do crime e da delinquência (...) nem traduz um passo adiante na eficiência do aparelho repressivo (...) também não é produto dos avanços da ciência criminológica” (2007, p. 28 e 29).

As categorias socialmente excluídas e encobertas, verdadeiros refugos - aquilo que pode ser descartado, pois não fará falta -, de jovens desempregados deixados à deriva, mendigos e 'sem tetos', nômades e toxicômanos deixados à sua própria sorte, imigrantes dos países em desenvolvimento, que chegam às costas do primeiro mundo sem documentos ou qualquer tipo de amparo.

Tais categorias, portanto, vão se tornando cada vez mais evidentes no espaço público, que atualmente se

\footnotetext{
${ }^{33}$ Sobre essa perspectiva de exclusão dos miseráveis, ou de qualquer outro que não se adequa ao modelo econômico, político e social do capitalismo neoliberal do século XX, Losurdo destaca o fato de atualmente os EUA se destacarem como o padrão ético, moral, político, econômico e social do resto do mundo, a não civilizada que deve atuar na busca de levar sua civilidade a todos os cantos do globo (2006, p. 21).

${ }^{34}$ Diante disso, Wacquant aponta que “à 'terrível miséria' dos bairros deserdados, o Estado responderá não com um fortalecimento de seu compromisso social, mas com um endurecimento de sua intervenção penal. À violência da exclusão econômica, ele oporá a violência da exclusão carcerária” (2001, p. 74).
} 
estrutura a partir de uma necessária e intensa competição, marca do individualismo neoliberal, de matiz excludente das diversidades, das diferenças, sobretudo, daquelas oriundas das relações econômico-sociais, bem como vão se alojando e corporificando aquilo que se denominou, ao longo do tempo, de: gueto $^{35}$, que no caso brasileiro, ficaram conhecidos - com algumas diferenças - enquanto favelas, morros, dentre outras alcunhas de locais onde o matáveis residem.

Uma característica marcante desse processo é a restrição a qual foram impostos os negros norteamericanos, haja vista o fato de que:

A América trouxe para o conceito de gueto a restrição de pessoas ao interior de uma área específica e a limitação de sua liberdade de escolha com base na cor da pele. Os muros invisíveis do gueto negro foram erguidos pela sociedade branca, por aqueles que têm o poder (WACQUANT, 2008, p. 77).

Essas pessoas ${ }^{36} \mathrm{e}$, sobretudo os jovens desamparados do mínimo de presença estatal, social ou familiar em sua formação humana, cultural e, principalmente, política, formam a encarnação viva e ameaçadora da insegurança social, verdadeiro sentimento global nos dias atuais, de modo que seus comportamentos passam a ser vistos como intoleráveis, sua presença se torna indesejável (WACQUANT, 2007, p. 29 e 30), cabendo ao Estado dar um jeito nesses moleques ${ }^{37}$.

É nesse cenário, de um lado, de repúdio ao diferente, à pobreza, e de outro, de salvaguarda dos iguais daqueles que dominam um mercado de consumo cada vez mais violento - através, sobretudo, da formação de uma sociedade do medo, que Wacquant vem discutir como o Estado atual, ainda pautado nos dogmas da modernidade, passa a ser o locus principal dos mecanismos usados para a contenção do sentimento de

\footnotetext{
${ }^{35}$ Essa palavra aparece empregada a partir de uma análise da obra de Loic Wacquant, As duas Faces do Gueto. Desse modo, os guetos podem ser percebidos como produtos de uma dialética móvel e tensa entre hostilidade externa - da racionalidade dominante (branca, ocidental, masculina, burguesa, cristã e capitalista) e afinidade interna (a diferença que une), que se traduz no nível da consciência coletiva pela ambivalência. Portanto, é do isolamento imposto pelo exterior, que surge a necessidade de uma intensificação do intercâmbio social e da partilha cultural no interior dessas áreas, cada vez maiores e mais distantes do centro de consumo (WACQUANT, 2008, p. 82). Sobre a formação, a evolução e o que hoje é percebido como gueto, ver o próprio Wacquant (2008, cap. 5).

${ }^{36}$ Hoje não estão mais restritas a essa perspectiva racial - da cor da pele - mas, de outro lado, e muito mais a fundo, dizem respeito às questões cada vez mais ligadas à cultura, aos dogmas religiosos, políticos, econômicos e sociais. O oriente, o sul-global, a África, os índios latinos e, de um modo geral, os pobres do mundo, representam hoje uma ameaça a hegemonia do capital, seja porque não consomem, seja porque deseja desenfreadamente consumir. E nesse contexto, a juventude brasileira, cuja grande maioria ainda padece em ver a concretização dos direitos que o constituinte de 1988 lhes assegurou, pode ser violentada, ainda mais, através de uma redução da proteção constitucional e, consequente aumento do sistema penal.

${ }^{37}$ Segundo o Mapa do Encarceramento: os jovens do Brasil, da Secretaria-Geral da Presidência da República de 2014, os atos infracionais mais recorrentes no país, em 2012, eram o roubo representando um percentual de 39\% de todos os atos infracionais cometidos no país, seguido pelo tráfico de drogas (27\%). Em terceiro lugar, com porcentagem menor, ficaram os homicídios (9\%), seguidos pelos furtos (4\%). Os demais atos infracionais: porte de arma de fogo, tentativa de homicídio, latrocínio, estupro e sua tentativa variaram de $3 \%$ a $4 \%$. Segundo o referido estudo, "no Brasil, em 2012, apenas $11 \%$ dos adolescentes que cumpriam medida socioeducativa restritiva de liberdade cometeram atos infracionais considerados graves, como homicídio e latrocínio" (2014, p. 71). Importante destacar nesse sentido, que dos jovens entre 15 e 29 anos que morreram no Brasil à época do estudo, por causas externas, $38,7 \%$ deles se deveu a prática de homicídios, sendo que $53,8 \%$ dessas mortes se deram frente a jovens com idade entre 15 a 19 anos, e mais, que morreram 73\% a mais de negros do que de brancos (2014, p. 72-73).
} 
insegurança, o que se dará por meio do encarceramento em massa ${ }^{38}$ de todos os que estiverem em conflito com a lei, independentemente da idade.

Ademais, as palavras de Domenico Losurdo acerca da construção racional das potências mercadológicas do Ocidente sobre o combate ao terrorismo ${ }^{39}$ servem para destacar claramente como o sentimento de insegurança - universalizado pela racionalidade de combate ao outro da modernidade, e ainda hoje presente nas relações entre os dominadores e os dominados - legitima qualquer violação aos direitos do diferente, aqui, vistos como a juventude pobre brasileira, principal vítima das propostas de redução da maioridade penal destacadas acima, a partir do momento em que "a ideia de que os 'assassinos' ou os 'terroristas' devem ser procurados entre os povos coloniais, e de que contra ele é legítimo, ou pelo menos compreensível, o recurso a todo tipo de arma" (2010, p. 52-53).

Portanto, todos aqueles e, sobretudo os jovens da periferia, que não conseguem integrar o centro de consumo e que, via de consequência, não fazem parte desse mercado, que domina, cada vez mais, as relações humanas, devem ser detidos a fim de se proteger todo esse complexo de formação e dominação dos mecanismos neoliberais - é aqui, conforme destacado acima, que surge um fenômeno social que corroborará as prisóes da miséria.

A desigualdade social, a subalternidade dos excluídos do centro de consumo pelo mercado, não será combatida através de efetivação de políticas públicas capazes de lhes garantir transformação, emancipação e libertação social, mas ao contrário, será combatida a partir de um Estado cada vez mais penalizado ${ }^{40}$.

\footnotetext{
${ }^{38}$ Segundo o Mapa do Encarceramento: os jovens do Brasil, da Secretaria Geral da Presidência da República, de 2014, entre os anos de 2005 e 2012, houve um aumento de 74\% no número de presos. E mais, que em 2012 - ano do levantamento - $68 \%$ dos presos eram presos condenados, $31 \%$ eram presos provisórios e $1 \%$ estava cumprindo medida de segurança. Ademais, importante destacar que o mesmo estudo aponta que apenas $1,2 \%$ dos presos brasileiros à época tinham ensino superior completo, o que demonstra o papel importante da ampliação das oportunidades de acesso ao ensino profissionalizante e superior, bem como o fato de que com o aumento do encarceramento, aumentou-se o encarceramento da população negra, chegando a aproximadamente 61\% dos presos em 2012, contra 58\% em 2005. Em 2012, para cada grupo de 100 mil habitantes brancos acima de 18 anos havia 191 brancos encarcerados, enquanto para cada grupo de 100 mil habitantes negros acima de 18 anos havia 292 negros encarcerados, ou seja, proporcionalmente o encarceramento de negros foi $1,5 \mathrm{vez}$ maior do que o de brancos em 2012. Para mais informações, ver Brasil (2014).

${ }^{39}$ Segundo Domenico Losurdo na busca pelo combate ao terrorismo antiamericanista, os EUA se tornaram o verdadeiro e supremo Senhor da Guerra. Em interpretação de Kant, Losurdo destaca que um monarca absoluto é aquele que, quando ordena faça-se a guerra -, a guerra se faz, de modo que os EUA podem ser vistos hoje, neste contexto, como o "(...) soberano planetário não vinculado nem limitado por nenhum organismo internacional" (2006, p. 159), ou seja, "(...) a Casa Branca decide a ocupação militar desses países de modo soberano, quando as decisões da $\mathrm{ONU}$ são vinculantes ou quando não o são; decide soberanamente quem são os estados fora-da-lei contra os quais é lícito impor um embargo, esfaimando um povo inteiro, ou quando é lícito despejar um inferno de chamas, inclusive mísseis com urânio empobrecido e bombas de fragmentação, que continuam a atingir população civil bem depois de findo o conflito (2006, p. 158).

${ }^{40}$ Sob esse aspecto, Carvalho apontará para o fato de que "as raízes desse processo de seletividade do sistema penal, a partir dos componentes sociais e raciais dos indivíduos e grupos criminalizados, evidência dos sintomas do processo de gestão da subcidadania protagonizada pelo campo penal, possuem fontes imaginárias bastante precisas. Como amplamente debatido, a grande "instituição de sequestro" que consistiu o território brasileiro projetou sobre as populações nativas e escravizadas um gigantesco trabalho de disciplinamento e controle absoluto, caracterizados pela segregação, pelo isolamento, pela destruição de
} 
O não desenvolvido, ou seja, aquele que recorre a processos cada vez maiores de migração para outros Estados, no âmbito internacional, bem como à sua clandestinização através do tráfico de entorpecentes ou da participação em grupos armados para a prática de furtos e roubos (crimes que representam o grande quantitativo dos atos infracionais cometidos pelos adolescentes e jovens em conflito com a lei no Brasil), a fim de conseguir um patamar de vida mais condizente com a sociedade de consumo em que vive, deve ser restringido, violentado cultural e socialmente, excluído e, o quanto antes, encarcerado ${ }^{41}$.

Importante marca desse movimento de recrudescimento do direito penal, frente àqueles que não cumprem com a agenda globalizada do mercado do capital, que estão excluídos do acesso aos bens básicos de seu desenvolvimento digno enquanto pessoa humana, aparece em Wacquant (2001, p. 16 e ss.) a partir da experiência norte americana, que posteriormente se espalhou pela Europa e, nas últimas décadas, parece ter desaguado aqui no Brasil, conhecida como a política da tolerância zero ${ }^{42}$.

Visando combater a marginalidade, a violência urbana e o desrespeito a lei e a ordem, essa política inseriu a busca, através do aparato policial do Estado, ou seja, da força cogente do Estado, do combate extremo a todos e

toda a rede cultural e simbólica das populações subjulgadas, consideradas inferiores, selvagens ou bárbaras aos olhos do conquistador (2014, p. 213).

${ }^{41}$ É importante ressaltar, ainda nesse contexto, que existem outros fatores de encobrimento que não se restringem ao econômico, tais como: o racial e o cultural, que surgem no contexto social a partir de um processo que Wacquant vai denominar como descivilização e demonização do outro. Aqui Wacquant demonstrará - a partir de um processo desencadeado na sociedade norteamericana - um processo cultural de descivilização (a redução do Estado, ou seja, do público, atuante no núcleo segregado da sociedade norte-americana) e de demonização (do subproletariado urbano negro - e atualmente, também, hispânico - que passam a ser vistos, mais do como uma classe inferior, uma parcela social que pode sofrer qualquer tipo de violação de direitos - por sua simples existência -, a fim de proteger uma classe dominante, hegemônica, que lhe é superior). Segundo Wacquant (2008, p. 34 e 35) o processo de Descivilização pode ser separado em quatro momentos, são eles: a) uma modificação estrutural das relações sociais, da forma e da densidade das 'figurações' sociais, que se manifesta tanto no aumento da divisão do trabalho quanto no prolongamento e multiplicação das redes de interdependência e interação entre indivíduos e grupos; b) uma série de mudanças associadas a modos e estilos de vida: a repressão e a privatização de funções corporais, a institucionalização e a difusão de formas de cortesia e o aumento da identificação mútua que leva a um declínio da violência interpessoal; c) uma individualização do comportamento social, ou seja, um aumento da pressão no sentido da racionalização da conduta, em especial pela elevação do patamar de vergonha e constrangimento e, ao fim, d) uma última transformação desse processo atinge os modos de conhecimento, cujo conteúdo fantasmático regride à medida que se afirmam os princípios da neutralidade cognitiva e da congruência com a realidade. Por outro lado, o processo de Demonização, ou a formação de um novo grupo social - o underclass - caracterizado por uma desordem à luz do padrão nacional do ser. Essa parcela social sofre essa estigmatização, pois é caracterizada por uma sexualidade fora do controle, as famílias são chefiadas por mulheres, há altas taxas de absenteísmo e reprovação nas escolas, há consumo e tráfico de drogas - além de uma propensão a criminalidade e a violência -, também, são dependentes do auxílio do público, o desemprego é altíssimo e, por fim, toda essa parcela social é amontoada em áreas - geralmente afastadas do centro de consumo da racionalidade moderna ocidental do Estado capitalista - cuja densidade de famílias problemáticas é alta (WACQUANT, 2008, p. 43 e 44).

${ }^{42}$ Sobre a referida teoria da tolerância zero, Wacquant apontará para o fato de que "essa teoria, jamais comprovada empiricamente, serve de álibi criminológico para a reorganização do trabalho policial (...). O objetivo dessa reorganização: refrear o medo das classes médias e superiores - as que votam - por meio da perseguição permanente dos pobres nos espaços públicos (ruas, parques, estaçōes ferroviárias, ônibus, metrô, e etc.). (...) desembocando em uma aplicação inflexível da lei sobre direitos menores tais como a embriaguez, a jogatina, a mendicância, os atentados aos costumes, a simples ameaça e "outros" comportamentos anti-sociais associados aos sem-teto. (...) os pequenos passadores de drogas, as prostitutas, os mendigos, os vagabundos, os pichadores. Em suma, o subproletariado que suja e ameaça. É nele que se centra prioritariamente a política do "tolerância zero" visando restabelecer a "qualidade de vida" dos nova-iorquinos que, ao contrário, sabem se comportar em público" (2001, p. 16-17). 
quaisquer delitos, sobretudo os menores, praticados, em sua grande maioria, por pobres, desempregados, mendigos, sem-teto, pessoas que representavam nos EUA, a classe social tida como problemática, eminentemente formada por pobres, negros e latinos.

A partir de então, ao se combater qualquer tipo de delito a ferro e fogo, a política da tolerância zero possibilitou o encarceramento em massa de pessoas que cometeram pequenos delitos, ditos como vetor para delitos mais graves, queriam, portanto, com essa perspectiva, cortar o mal pela raiz.

Em contextos sociais, políticos, econômicos e culturais diversos da sociedade norte americana, tais como as sociedades latino-americanas, nas quais se insere o Brasil, um país de modernidade tardia, periférico, as premissas da tolerância zero, de recrudescimento do direito penal, da formação de um Estado policialesco, e de percepção do direito penal como vetor de transformação social, provocará mais mal do que bem, pois

Em tais condições, desenvolver o Estado penal para responder às desordens suscitadas pela desregulamentação da economia, pela dessocialização do trabalho assalariado e pela pauperização relativa e absoluta de amplos contingentes do proletariado urbano, aumentando os meios, a amplitude e a intensidade da intervenção do aparelho policial e judiciário, equivale a (r)estabelecer uma verdadeira ditadura sobre os pobres (WACQUANT, 2001, p. 6).

A partir dessas premissas é possível percebermos que objetivar diminuir a violência, o sentimento de impunidade e o alto nível de criminalidade no Brasil, através da redução da maioridade penal, do recrudescimento do aparelho penal do Estado, cada vez mais cedo, àqueles que cometeram algum tipo de desvio frente aos padrões da normatividade político-social, estampada pela ordem jurídica do Estado, pode, como debatido acima, além de não solucionar o problema, agravar, ainda mais, a exclusão daqueles que, à margem da sociedade, não têm no Estado um instrumento de efetivação de seus direitos.

\section{INCONCLUSIVAS CONCLUSÕES ${ }^{43}$}

Em uma sociedade como a brasileira, estruturada desde seus primórdios a partir de uma nítida dominação de classes, através, sobretudo, de uma divisão irregular das riquezas do país, é evidente que diversos graus de violência, seja ela física, política, cultural, social ou econômica, serão exercidos sobre os grupos dominados, neste caso, a classe mais excluída e pobre, reduto, nos grandes centros, de retirantes vindos de outros estados, ou de negros, ainda a grande população das comunidades (favelas) e "guetos" brasileiros.

Uma das formas de exercitar essa dominação, dentre muitas outras, é a partir da criação de toda uma ideologia para justificá-la, tal como se apresenta com o discurso da necessidade de redução da maioridade penal a fim de se diminuir a impunidade, bem como o medo e a insegurança urbana no país, que faz com que essa situação de autoritarismo, de recrudescimento penal e de surgimento de um Estado policialesco, seja vista como

\footnotetext{
${ }^{43}$ Essa expressão é emprestada de COUTO (2011, p. 197-202).
} 
algo extremamente necessário.

A partir de tais circunstâncias, portanto, é possível compreender que um dos principais objetivos, premente a todo esse discurso a favor da redução da maioridade penal como instrumento de extermínio da impunidade e da violência, se traduz em uma espécie de opressão que, em contextos instáveis, política e, em especial, economicamente, como o atual, acaba convencendo os oprimidos de que eles estão nessa situação, não em razão do fato de que existem outros que os oprimem, mas porque eles vivem a hostilidade de um ambiente, onde o preço de sua segurança é a arbitrariedade e o autoritarismo.

Ou seja, as atrocidades e violências cometidas pelo Estado policialesco, contra tudo e contra todos, toda vez que sobe o morro, invadindo, quebrando, dando pescoçóes, na verdade podem ser vistas como atitudes corretivas e educativas, pois, assim como nossos pais, que na infância nos dizem que a injeção que vamos tomar vai doer, mas que é para o nosso bem, todo recrudescimento do Estado policialesco se dá para o bem desses excluídos - onde se encontram, conforme dados acima, a grande parcela dos jovens delinquentes e que serão o principal alvo de uma possível redução da maioridade penal.

A redução da maioridade penal, diante de todas essas premissas, é um caminho - atualmente o escolhido como o mais racional e evidente, por aqueles que defendem o aumento desse Estado policialesco destacado acima - que poderá se mostrar ineficaz, haja vista, nos termos destacados no capítulo primeiro desta pesquisa, ser capaz de concretizar o extermínio de uma grande parcela social que, muito antes de desenvolver sua condição humana por meio de uma proteção integral e prioritária de direitos básicos à sua cidadania terá, condicionalmente, no cárcere, o principal e único instrumento para sua formação social, política, cultural e, sobretudo, econômica.

Neste sentido, conforme destacado no capítulo dois acima, o sentimento de impunidade, o medo, o modelo de sociedade neoliberal, individualista, patrimonialista, ínsito, a partir da década de 1980 aos contextos de países periféricos como o Brasil, aliado às crises econômicas que aceleram o empobrecimento através do desemprego em massa, dentre outras características, dá origem ao Estado de Exceção, onde tudo se pode, onde a penalização, cada vez mais cedo, dos excluídos desse cenário mercadológico, capitalista e consumista, é o melhor caminho para a solução, em tempos de crise, dos índices de violência e do sentimento de medo que hoje é, insistentemente, promovido pelos mais diversos meios de comunicação em massa no país.

É nesse Estado de Exceção que a punição, o aumento do poder de vigilância do Estado se traduzirá na necessidade de se promover um maior número de prisões, o que acabará recaindo sobre os mais pobres, deflagrando fenômenos como as prisões da miséria, destacado aqui a partir de Loic Wacquant.

Por fim, antes de buscarmos discutir a redução, ou não, da maioridade penal no contexto brasileiro, deveríamos buscar discutir a efetivação das promessas constitucionais a todos, e não somente aos que cumprem determinadas características desse modelo de Ser (neoliberal, consumista, capitalista e globalizado), pois o 
objetivo maior do Estado deve sempre ser, sem distinção, ou opção, por pessoas, a melhoria da vida humana, a efetivação do bem comum, pois o que realmente nos importa, ao final dessa viagem que é a vida, é se estaremos felizes com o passeio, ou com raiva do motorista!

\title{
THE REDUCTION OF CRIMINAL AGE AND THE PEC 171/1993: A DEBATE ON THE STATE OF EXCEPTION AND THE PRISONS OF POVERTY
}

\begin{abstract}
The issue of reducing the legal age in Brazil is not recent debate - whether in academia or in legal practice, either on the day of Brazilians - as long stands as a point of conflict of opinions in various sectors of society. Therefore, this research will seek to understand, from some theoretical frameworks, as Hannah Arendt, Loic Wacquant, Zygmunt Bauman, Raul Eugenio Zaffaroni, Domenico Losurdo, Giorgio Agamben, among others, and in a methodological perspective of multiple-dialectical, such reduction may be an agent of violation of fundamental rights of the human condition of Brazilian youth, concluding in the end that the criminal upsurge, increased criminal State in the search for solution to problems such as urban violence, the feeling of impunity, is not the best way, for the victims of police state is, even more, the poorer classes of society, so that the criminal law does not appear as the best mechanism for the civilization of Being.
\end{abstract}

Keywords: Human Condition; Minor Offender; State of Exception; Prisons of Poverty; PEC 171/1993.

\section{REFERENCIAS}

AGAMBEN, Giorgio. Estado de Exceção. 2aed. São Paulo: Boitempo, 2004.

Homo Sacer: o poder soberano e a vida nua. Belo Horizonte: Editora UFMG, 2002.

ARENDT, Hannah. Origens do Totalitarismo. trad. Por RAPOSO, Roberto. São Paulo: Companhia das Letras, 2007. 2014.

A Condição Humana trad. por RAPOSO, Roberto. 12aed. rev. Rio de Janeiro: Forense Universitária, $\overline{02,2005}$

Trabalho, Obra, Ação. trad. por CORREIRA, Adriano. In.: Cadernos de Ética e Filosofia Política, n. 7, vol.

Public Rights and Private Interests. In:: MOONEY, M. and STUBER, F. Small Comforts for Hard Times: Humanists on Public Policy. New York: Columbia University Press, 1977.

BARATTA, Alessandro. Criminologia Crítica e Crítica do Direito Penal. $3^{a}$ ed. Rio.

BAUMAN, Zygmunt. Capitalismo Parasitário. Rio de Janeiro: Jorge Zahar, 2010.

Medo líquido. Rio de Janeiro: Jorge Zahar, 2008.

Zahar, 1998

O mal-estar da pós-modernidade. Trad. de Mauro Gama e Claudia Martinelli. Rio de Janeiro: Jorge

Vida para Consumo: a transformação das pessoas em mercadoria trad. por MEDEIROS, Carlos Alberto. Rio de Janeiro: Zahar, 2008. 
BRASIL, Presidência da República/Secretaria-Geral da Presidência da República. Mapa do Encarceramento: os jovens do Brasil. Brasília/DF, 2014.

CARVALHO, Thiago Fabres. Criminologia, (In)Visibilidade, Reconhecimento - o controle penal da subcidadania no Brasil. Rio de Janeiro: Editora Revan, 2014.

CORREIA, Adriano. "Pensar o que Estamos Fazendo". In: ARENDT, Hannah. A Condição Humana trad. por RAPOSO, Roberto. 12aed. rev. Rio de Janeiro: Forense Universitária, 2014.

COUTO, Mia. E se Obama fosse Africano?. Artigo publicado no jornal Savana, Maputo. In.: E se Obama Fosse Africano?: e outras intervenções. São Paulo: Companhia das Letras, 2011.

FOUCAULT, Michel. Vigiar e Punir. 32 ed. Petrópolis: Vozes, 2006.

FORRESTER, Viviane. O Horror Econômico. trad. por LORENCINI, Álvaro. São Paulo: Editora da Universidade Estadual Paulista, 1997.

GALEANO, Eduardo. Os Numerinhos e as Pessoas. In.: GALEANO, Eduardo. O Livro dos Abraços. Trad. por NEPOMUCENO, Eric. Porto Alegre: L\&PM, 2005.

Os Invisíveis. In.: GALEANO, Eduardo. O Teatro do Bem e do Mal. Trad. por FARACO, Sérgio e OUTRO. Porto Alegre: L\&PM, 2006.

KROHLING, Aloísio. Dialética e Direitos Humanos - múltiplo-dialético - da Grécia à contemporaneidade. Curitiba: Juruá, 2014.

LOSURDO, Domenico. A Linguagem do Império - léxico da ideologia estadunidense. trad. por CLASEN, Jaime A.. São Paulo: Boitempo, 2010.

Liberalismo: entre civilização e barbárie. trad. por JOFFILY, Bernardo e OUTRO. São Paulo: Anita Garibaldi, 2006.

MELOSSI, Dario e PAVARINI, Massimo. Cárcere e Fábrica - as origens do sistema penitenciário (séculos XVIXIX). 2aed. Rio de Janeiro: Editora Revan, 2010.

NIETZSCHE, F. Aurora trad. por SOUZA, Paulo César de. São Paulo: Companhia das Letras, 2004.

ROSENFELD, Michel. A Identidade do Sujeito Constitucional. Tradução de Menelick de Carvalho Netto. Belo Horizonte: Mandamentos, 2003.

A Identidade do Sujeito Constitucional e o Estado Democrático de Direito. In.: Cadernos da Escola do Legislativo. v. 7, nº 12, p. 11-63, jan./jun., Belo Horizonte, 2004.

SANTOS, Boaventura de Souza. Para Além do Pensamento Abissal: das linhas globais a uma ecologia dos saberes. In: Revista Crítica de Ciências Sociais, n. 78, Outubro de 2007, p. 3-46.

VIEIRA, Ana Lucia Menezes. Processo penal e mídia. São Paulo. RT, 2003.

WACQUANT, Loic. As Duas Faces do Gueto. trad. por CASTANHEIRA, Paulo Cesar. São Paulo: Boitempo, 2008.

As Prisões da Miséria trad. por TELLES, André. Rio de Janeiro, Jorge Zahar, 2001. 
Punir os Pobres: a nova gestão da miséria nos Estados Unidos. trad. por LAMARÃO, Sérgio. 3aed. rev. e ampl. Rio de Janeiro, 2007.

WALLERSTEIN, Immanuel Maurice. Capitalismo Histórico e Civilização Capitalista. Rio de Janeiro: Contraponto, 2001.

WERMUTH, Maiquel Ângelo Dezordi. Medo e Direito Penal: Reflexos da Expansão Punitiva na Realidade Brasileira. São Paulo: Livraria do Advogado, 2011.

ZAFFARONI, Eugenio Raúl. A palavra dos mortos. São Paulo: Saraiva, 2012.

A questão criminal. Rio de Janeiro: Revan, 2013.

2013

O Inimigo no Direito Penal. Trad. Por LAMARÃO, Sérgio. 3aed. 1a reimp. Rio de Janeiro: Editora Revan,

ZIZEK, Slavoj. O Espectro da Ideologia. In: ZIZEK, Slavoj (org). Um Mapa da Ideologia. Rio de Janeiro, 1996.

Vivendo no Fim dos Tempos. Trad. por MEDINA, Maria Beatriz de. São Paulo: Boitempo, 2012.

Trabalho enviado em 07 de março de 2016.

Aceito em 16 de junho de 2016. 